\title{
Factors affecting patient tolerance of unsedated upper gastrointestinal tract endoscopy
}

\section{Czynniki wpływające na tolerancję endoskopii górnego odcinka przewodu pokarmowego bez sedacji}

\author{
Barbara Maślanka-Seiffert ${ }^{1,2, A, B, D, D, F}$, Piotr Seiffert ${ }^{3, A, B, B, F}$, Agnieszka Olchowska-Kotala ${ }^{4, C, E, F}$, Radosław Kempiński ${ }^{5, A, E, E, F}$ \\ ${ }^{1}$ Department of Gastroenterology and Hepatology, Medical University of Silesia, Katowice \\ ${ }^{2}$ Geriatric Ward, The Municipal Hospital of Chorzów, Poland \\ ${ }^{3}$ John Paul II Geriatric Hospital, Katowice, Poland \\ ${ }^{4}$ Department of Humanistic Sciences in Medicine, Wroclaw Medical University, Poland \\ ${ }^{5}$ Department of Gastroenterology and Hepatology, Wroclaw Medical University, Poland \\ A - research concept and design; B - collection and/or assembly of data; $\mathrm{C}$ - data analysis and interpretation; \\ $\mathrm{D}$ - writing the article; $\mathrm{E}$ - critical revision of the article; $\mathrm{F}$ - final approval of the article
}

\section{Address for correspondence}

Piotr Seiffert

E-mail: piotrseiffert@gmail.com

Funding sources

None declared

Conflict of interest

None declared

Received on 0ctober 17, 2018

Reviewed on January 2, 2019

Accepted on September 9, 2019

Cite as

Maślanka-Seiffert B, Seiffert P, Olchowska-Kotala A,

Kempiński R. Factors affecting the tolerance of the unsedated upper gastrointestinal tract endoscopy. Piel Zdr Publ. 2020;10(1):13-18. doi:10.17219/pzp/112223

DOI

$10.17219 / \mathrm{pzp} / 112223$

\begin{abstract}
Background. Endoscopy of the upper gastrointestinal tract is a widely used diagnostic procedure. It can be a source of anxiety, discomfort and even pain for the patients.

Objectives. The aim of the study was to assess the discomfort and anxiety associated with gastroscopy, examine their determinants and describe patients' preferences regarding medical procedures and personnel behavior.
\end{abstract}

Material and methods. The study involved 50 patients (21 men and 29 women) who underwent an endoscopy of the upper gastrointestinal tract. The State-Trait Anxiety Inventory (STAI) was employed, as well as the authors' own two-part questionnaire, which was conducted before and after the endoscopy.

Results. The average level of anxiety was 40.72 STAl points and the emetic reflex was its main source (52\%). The average level of discomfort felt during the gastroscopy was 2.84 and was related to both age $(p=0.001)$, security and privacy during the examination $(p=0.03)$, as well as to the level of anxiety prior to examination $(p=0.05$ ). The severity of the discomfort was not associated with gender, education or subjective assessment of knowledge about the examination. Half of the patients would have liked to be sedated. A majority of the respondents (61\%) indicated that verbal reassurance is a desirable form of behavior of the medical staff.

Conclusions. The main cause of patients' anxiety is fear of the discomfort associated with the emetic reflex. The discomfort experienced by patients during endoscopy is linked to their age group, with younger participants experiencing greater discomfort, higher levels of anxiety prior to the examination, and a lower sense of security and privacy. Patients value verbal reassurance, procedural information and behavioral instructions during the endoscopy. General sedation is preferred by patients.

Key words: anxiety, gastroscopy, discomfort

Copyright

○ 2020 by Wroclaw Medical University

This is an article distributed under the terms of the

Creative Commons Attribution 3.0 Unported License

(https://creativecommons.org/licenses/by/3.0/) 


\section{Streszczenie}

Wprowadzenie. Endoskopia górnego odcinka przewodu pokarmowego jest rozpowszechnionym badaniem diagnostycznym. Może stanowić dla pacjenta źródło lęku, dyskomfortu, a nawet bólu.

Cel pracy. Celem badania była ocena dyskomfortu i lęku związanego z gastroskopią, zbadanie ich determinantów oraz określenie oczekiwań pacjentów odnośnie do procedur medycznych i zachowania personelu.

Materiał i metody. Przebadano 50 pacjentów (21 mężczyzn i 29 kobiet) poddanych endoskopii górnego odcinka przewodu pokarmowego. Do badania wykorzystano Inwentarz Stanu i Cechy Lęku STAl oraz dwuczęściową autorską ankietę przeprowadzaną przed endoskopią i po niej.

Wyniki. Średni poziom lęku wynosił 40,72 pkt STAl, a odruch wymiotny byłjego głównym źródłem (52\%). Średni poziom odczuwanego dyskomfortu podczas gastroskopii wynosił 2,84 i był związany zarówno z wiekiem $(p=0,001)$, bezpieczeństwem i prywatnością podczas badania $(p=0,03)$, jak i poziomem lęku przed badaniem $(p=0,05)$. Nasilenie dyskomfortu nie było związane z płcią, wykszzałceniem i subiektywną oceną wiedzy o badaniu. Połowa pacjentów zadeklarowała chęć użycia sedacji. Spośród respondentów 61\% wskazało, że wsparcie werbalne jest pożądaną formą zachowania personelu medycznego.

Wnioski. Główną przyczyną niepokoju pacjentów jest lęk przed dyskomfortem związanym z odruchem wymiotnym. Dyskomfort odczuwalny podczas endoskopii jest większy u młodszych pacjentów, związany z wyższym poziomem lęku przed badaniem i mniejszym poczuciem bezpieczeństwa i prywatności. Pacjenci doceniają wsparcie werbalne, informacje proceduralne i instrukcje behawioralne podczas endoskopii, a także oczekują możliwości zastosowania optymalnej sedacji.

Słowa kluczowe: lęk, gastroskopia, dyskomfort

\section{Introduction}

Endoscopic examination of the upper gastrointestinal tract is a widespread diagnostic method. The use of modern thin and flexible videoendoscopes has made the procedure less invasive. Bleeding and perforation are the major complications observed during the examination; however, during diagnostic endoscopies these complications occur very rarely. ${ }^{1,2}$ Endoscopies are usually performed using pharyngeal anesthesia or, in some cases, short intravenous sedation.

Subjective impressions related to gastroscopy appear to be extremely important not only from the patient's perspective. Anxiety related to the examination correlates with discomfort during its performance and with lower individual tolerance, ${ }^{3,4}$ which in some cases greatly influences the course of the examination, its duration and the occurrence of potential complications. ${ }^{5}$ Anxiety accompanies patients from their referral to the waiting room immediately before the examination, during it, and while awaiting the examination results. ${ }^{6}$

The aims of the study were: (1) to assess the discomfort related to gastroscopy and to determine the factors influencing it; (2) to examine the anxiety associated with gastroscopy and its determinants; and (3) to describe patients' preferences regarding medical procedures and personnel behavior.

\section{Material and methods}

The study involved 50 randomly selected patients of the Department of Gastroenterology and Hepatology of Wroclaw Medical University, Poland: 21 men and 29 women aged from 19 to 85 years. The mean age was
55 years (standard deviation $(S D)=16.18$ ). The demographic structure of the study group is presented in Table 1. The research protocol is in accordance with the Helsinki Convention and all participants of the study gave their informed consent to participate in the study. Indications to perform endoscopy included dyspepsia and laboratory abnormalities. All of the patients underwent endoscopy of the upper gastrointestinal tract using local anesthesia of throat mucosa with a $10 \%$ lidocaine spray. Intravenous sedation was not used. Among the participants, 77\% had undergone at least 1 previous gastroscopy.

The data collection was conducted in 2 stages. First, 1 day preceding the endoscopy, the State-Trait Anxiety Inventory (STAI) and the authors' questionnaire were conducted; the $2^{\text {nd }}$ part was conducted after the gastroscopy and included questionnaire items about the course of the examination.

Table 1. Demographic structure of the study group

Tabela 1. Struktura demograficzna badanej grupy

\begin{tabular}{|l|c|c|}
\hline Variable & $n$ & $\%$ \\
\hline Gender & & \\
women & 29 & 58 \\
men & 21 & 42 \\
Education & & \\
$\quad$ basic & 6 & 12 \\
vocational & 16 & 32 \\
secondary & 11 & 22 \\
university & 17 & 34 \\
Place of residence & & \\
$\quad$ village & 13 & 26 \\
city & 37 & 74 \\
Previous gastroscopy & & \\
yes & 38 & 76 \\
no & 12 & 24 \\
\hline
\end{tabular}

$n$ - sample size. 
The level of anxiety was measured using the Polish version of the STAI I. ${ }^{7}$ The STAI I is a commonly used 20 -item self-report scale for measuring anxiety as a state. It requires patients to describe how they feel at the moment, using four-point scales where 1 indicates relaxation and higher scores show increasing anxiety. The STAI was used to assess the level of a patient's anxiety prior to the examination.

To assess the patient's perceptions, distressing feelings and preferences associated with gastroscopy, a questionnaire developed for this study was used. The first part, which was conducted prior to the gastroscopy, included questions about any previous gastroscopy and the patient's source of knowledge about the examination. It also explored patients' preferences regarding the course of the examination: whether the patient would like to observe the examination on a monitor, whether they would like the presence of a friend/relative during the gastroscopy and whether they wanted intravenous anesthesia to be administered. The questionnaire also included items about the main cause of anxiety associated with the procedure. The $2^{\text {nd }}$ part of the questionnaire was completed after the gastroscopy. Using a numerical scale from 0 to 10 , where 0 was none and 10 the highest level, patients described the level of discomfort and their sense of security and privacy experienced during the gastroscopy. Patients were also asked about the most desirable behavior of medical personnel during the gastroscopy (verbal reassurance, procedural information and behavioral instructions, tactile contact). It was possible to indicate more than 1 behavior.

The statistical analysis was performed using SPSS statistical software, v. 18 (SPSS Inc., Chicago, USA); $p$-values $<0.05$ were considered statistically significant. The sample characteristics were examined using descriptive statistics. Regression analysis was performed in order to determine the factors influencing discomfort during a gastroscopy.

\section{Results}

The following variables were entered in the regression model: anxiety as a state, the self-assessment of knowledge of gastroscopy before the examination, assessment of safety and privacy during the examination, and demographic variables: gender, age and education. The model turned out to be well adjusted to the variables $(F(6.43)=5.531$; $p<0.001)$. Overall, the variables accounted for $36 \%$ of the variation in discomfort (adjusted $r^{2}=0.36$ ).

As shown in Table 2, the discomfort experienced by patients during their endoscopies was significantly associated with their age, level of anxiety, and sense of security and privacy. The patients' subjective assessments of their knowledge about the procedure, their gender and education did not affect the intensity of discomfort. The average level of discomfort (range: 0-10) was 2.84 (SD = 3.42).

The average level of anxiety was 40.72 points (the possible range is from 20 to 80 ). Slightly more than half of the patients declared that the emetic reflex was a major source of anxiety before the examination. Pain, the examination result and complications were other causes of anxiety (Table 3).

Most patients' knowledge about the course and aim of the procedure was derived from previous experience. Family and friends were a further source of information. Only $22 \%$ of the respondents reported that their physicians were a source of knowledge. A small group of patients listed the Internet and newspapers as sources of information. The average declared level of knowledge according to the patients' self-assessment was $5.74(S D=2.53)$ on a $0-10$ scale.

The patients' preferences as to the course of the examination are presented in Table 3 . The majority of respondents did not want the presence of a relative/friend during the gastroscopy; nor did they want to observe the examination on a monitor. In the questionnaire that preceded the endoscopy, the patients were asked if they would have liked to be subjected to intravenous anesthesia if it had

Table 2. Factors affecting discomfort during gastroscopy $(N=50)$

Tabela 2. Czynniki wpływające na dyskomfort odczuwany podczas gastroskopii $(N=50)$

\begin{tabular}{|c|c|c|c|c|c|}
\hline Variable & $M$ & $S D$ & $\beta$ & $t$-value & $p$-value \\
\hline $\begin{array}{l}\text { Anxiety } \\
\text { [STAl points] }\end{array}$ & 40.72 & 9.81 & 0.25 & 1.98 & $0.05^{a}$ \\
\hline $\begin{array}{l}\text { Knowledge about examination } \\
\text { (range 0-10) }\end{array}$ & 5.74 & 2.53 & -0.02 & -0.18 & 0.86 \\
\hline $\begin{array}{l}\text { Safety and privacy } \\
\text { (range } 0-10 \text { ) }\end{array}$ & 8.58 & 2.49 & -0.28 & -2.23 & $0.03^{a}$ \\
\hline Gender & - & - & -0.02 & -0.15 & 0.88 \\
\hline Age & - & - & -0.47 & -3.99 & $0.001^{a}$ \\
\hline Education & - & - & 0.04 & 0.31 & 0.76 \\
\hline
\end{tabular}

a Statistically significant values.

M - mean; $\beta$ - linear regression coefficient; SD - standard deviation; STAI - State-Trait Anxiety Inventory. 
been possible; half of the respondents said they would. The vast majority of those who declared their willingness to have anesthesia administered were willing to pay for it. The average level of security and privacy during the examination was $8.58(S D=2.49)$. Reassurance from by the medical personnel was the behavior that the patients most appreciated; giving procedural information (i.e., what will happen next during the examination) and behavioral instruction (i.e., how the patient should behave afterwards) were also appreciated (Table 3).

Table 3. Participants' answers regarding sources of anxiety and preferences related to the examination

Tabela 3. Odpowiedzi ankietowanych pacjentów na temat źródeł lęku i oczekiwań związanych z badaniem

\begin{tabular}{|c|c|c|}
\hline Question & Answer & $\%$ \\
\hline \multirow{3}{*}{$\begin{array}{l}\text { Desire to observe } \\
\text { the examination on a } \\
\text { monitor }\end{array}$} & yes & 39 \\
\hline & no & 47 \\
\hline & don't know & 14 \\
\hline \multirow{3}{*}{$\begin{array}{l}\text { Presence of a friend/ } \\
\text { relative during the } \\
\text { examination needed }\end{array}$} & yes & 4 \\
\hline & no & 94 \\
\hline & don't know & 2 \\
\hline \multirow{5}{*}{ Anxiety source } & emetic reflex & 52 \\
\hline & pain & 17 \\
\hline & outcome & 8 \\
\hline & complications & 6 \\
\hline & other & 5 \\
\hline \multirow{5}{*}{$\begin{array}{l}\text { Knowledge about } \\
\text { the examination }\end{array}$} & own experience & 66 \\
\hline & friends, family & 23 \\
\hline & physician & 22 \\
\hline & internet & 14 \\
\hline & press & 9 \\
\hline \multirow{3}{*}{$\begin{array}{l}\text { The most desirable } \\
\text { behavior of medical } \\
\text { personnel }\end{array}$} & verbal reassurance & 61 \\
\hline & $\begin{array}{l}\text { procedural information and } \\
\text { behavioral instructions }\end{array}$ & 56 \\
\hline & physical contact & 23 \\
\hline
\end{tabular}

\section{Discussion}

The aim of the study was to assess the discomfort and anxiety associated with gastroscopy, to examine their determinants and to describe patients' preferences regarding medical procedures and personnel behavior. The results revealed that the discomfort predictors were higher anxiety before the examination, young age and a lower assessment of safety and privacy during the endoscopy. The results we obtained support previous reports indicating that high levels of anxiety prior to the examination may result in high levels of discomfort during gastroscopy, ${ }^{3,8,9}$ and may suggest that decreasing pre-procedural anxiety can result in reduced pain levels during the endoscopy and higher patient satisfaction. ${ }^{4}$ On the other hand, the relationship between discomfort and anxiety may suggest that a desirable level of sedation was not achieved, because this correlation is not observed in patients satisfactorily sedated with midazolam or propofol. ${ }^{10}$

The average level of anxiety was 40.72 STAI points, which is slightly lower than in other studies: 40.72 vs 45.7 tested immediately prior to the procedure ${ }^{11}$; or 40.72 vs 46.98 in non-hospitalized patients. ${ }^{12}$ The average level of discomfort in our study was lower than in a study by Mulcahy et al. (2.84 vs 5 on a $0-10$ scale). ${ }^{3}$

Some research indicates that an efficient method for reducing anxiety before an endoscopy is psychological intervention. ${ }^{13}$ One of the proposed techniques that lower the anxiety level is teaching the subjects methods to distract themselves from a procedure, which seems to be even more effective than practicing behaviors that are required during an endoscopy. Anxiety can also be reduced using other methods, such as listening to music. ${ }^{14}$

The main cause of the patients' anxiety in our study was fear of discomfort associated with the emetic reflex, pain, complications, and examination results, all of which are consistent with previous studies. ${ }^{5,15}$

The relationship between patients' younger age and greater discomfort experienced during the examination was also observed in earlier studies, in which older people felt less discomfort, and their examination tolerance was also greater. ${ }^{3,16,17}$ This may be explained by the fact that the emetic reflex is often impaired in older people. ${ }^{3}$ On the other hand, some research shows no relationship between tolerance and age. ${ }^{18}$

There are factors involved in preparing for the examination and carrying it out that have a significant impact on the well-being of the patient. Some studies suggest that reliable information before a gastroscopy has a positive influence on the patient's distressing feelings. ${ }^{19,20} \mathrm{Al}-$ though informational leaflets are successful at reducing anxiety, ${ }^{21}$ oral information seems to be more effective. ${ }^{17}$ An interesting observation reported in a similar study is that longer waiting times before receiving procedural information are correlated with higher anxiety. ${ }^{21}$

In our research, self-assessed levels of knowledge were not associated with discomfort. This result may be due to the fact that the patients described their level of knowledge about gastroscopy as moderate, and the knowledge that they have more often comes from friends and family than from the physician.

In this study, a large number of patients did not want to observe the examination on a monitor; it seems that it would be advisable to find out a given patient's preferences. This also applies to the presence of a friend/ relative during the examination. Only a small number of patients wanted to be accompanied by friends/family, although some research indicates it as an effective method of reducing patients' stress. ${ }^{22,23}$

Opinions on the use of sedation during endoscopy are ambiguous and changeable over time. Results from a vast European survey (29 countries) revealed that in the early 
2000s, in about half of the countries, routine diagnostic upper gastrointestinal tract endoscopy was performed with sedation in less than $25 \%$ of the patients, ${ }^{24}$ but several years later increases in the use of sedation have been observed, reaching for example $82 \%$ in Germany. ${ }^{25}$ Data from the USA and Australia show that the vast majority (98\%) of upper gastrointestinal tract endoscopies are performed with sedation. ${ }^{26,27}$ Sedation seems to be a result of patients' wishes more than endoscopists' preferences. In both the USA and Europe, the most popular sedatives are benzodiazepines and propofol. ${ }^{29,30}$

Greater comfort and higher patient tolerance for gastroscopy are the arguments in favor of the use of sedatives. Economic factors and possible side effects (cardiovascular and respiratory problems) are considered counterarguments. Some patients reject the use of sedation because it precludes any possibility of conversing with the doctor immediately after the gastroscopy. ${ }^{31}$ In our research, half of the patients declared willingness to undergo sedation; the majority of them stated that they would agree to pay for it themselves.

The behavior of the medical personnel had an impact on the patient's well-being during a gastroscopy and can improve the quality of care provided. ${ }^{27,32}$ The participants in our study wanted not only procedural information and behavioral instructions, but also verbal reassurance from the staff. Personnel should be particularly cautious about physical contact with the patient (such as hand-holding or a pat on the shoulder). Even though researchers indicate that tactile communication is important in the doctor-patient relationship, ${ }^{30}$ some studies have shown that physical contact does not correlate with patient satisfaction. ${ }^{33}$ In our study, less than $1 / 4$ of the participants indicated that tactile contact was desired. The endoscopist's technical and communication skills are more important to patients than socio-environmental factors such as single-sex surroundings, noise or privacy. ${ }^{34}$ Interventions based on improving staff knowledge and communication skills achieve promising results. ${ }^{27}$

The study limitations include the fact that the group of participants was heterogeneous in terms of diagnosis. Secondly, the results are based on a small convenience sample. Finally, we included neither differences arising from the different endoscopist's skills nor the duration of the examinations.

\section{Conclusions}

There are 4 conclusions of this study to be formulated for clinical practice:

1. The main cause of patient anxiety is the emetic reflex.

2. Discomfort experienced during endoscopy is associated with patients' younger age, higher anxiety prior to the examination and lower sense of security and privacy.
3. Patients value verbal reassurance, procedural information and behavioral instruction during the examination. 4. Patients favor general sedation.

\section{ORCID iDs}

Barbara Maślanka-Seiffert (D) https://orcid.org/0000-0002-5524-0760 Piotr Seiffert (D) https://orcid.org/0000-0001-7987-5640

Agnieszka Olchowska-Kotala (D) https://orcid.org/0000-0002-0719-4675 Radosław Kempiński (D) https://orcid.org/0000-0002-6030-2700

\section{References}

1. Lapalus M, Saurin J. Complications of gastrointestinal endoscopy: Gastroscopy and colonoscopy [in French]. Gastroenterol Clin Biol. 2003;27(10):909-921.

2. Levy I, Gralnek I. Complications of diagnostic colonoscopy, upper endoscopy and enteroscopy. Best Pract Res Clin Gastroenterol. 2016;30(5):705-718. doi:10.1016/j.bpg.2016.09.005

3. Mulcahy $H$, Kelly $P$, Banks $M$, et al. Factors associated with tolerance to, and discomfort with, unsedated diagnostic gastroscopy. Scandinavian J Gastroenterol. 2001;36(12):1352-1357. doi:10.1080/003655201317097245

4. Pontone S, Tonda M, Brighi M, Florio M, Pironi D, Pontone P. Does anxiety or waiting time influence patients' tolerance of upper endoscopy? Saudi J Gastroenterol. 2015;21(2):111-115. doi:10.4103/1319-3767.153839

5. Brandt L. Patients' attitudes and apprehensions about endoscopy: How to calm troubled waters. Am J Gastroenterol. 2001;96(2): 280-284. doi:10.1111/j.1572-0241.2001.03508.x

6. Chuah S, Goh K, Wong N. Common anxieties of patients undergoing oesophago-gastro-duodenoscopy, colonoscopy and endoscopic retrograde cholangio-pancreatography. Med J Malaysia. 1999;54(2):216-224.

7. Spielberger C, Gorsuch R, Lushene R. The State-Trait Anxiety Inventory: Test Manual. Palo Alto, CA: Consulting Psychologists Press; 1970.

8. Campo R, Brullet E, Montserrat A, et al. Identification of factors that influence tolerance of upper gastrointestinal endoscopy. Eur J Gastroenterol Hepatol. 1999;11(2):201-204. doi:10.1097/00042737 -199902000-00023

9. Hoya Y, Matsumura I, Fujita T, Yanaga K. The use of nonpharmacological interventions to reduce anxiety in patients undergoing gastroscopy in a setting with an optimal soothing environment. Gastroenterol Nurs. 2008;31(6):395-399. doi:10.1097 /SGA.0b013e31818eb5c9

10. Ünal HÜ, Korkmaz M, Özüçürümez G, et al. The effect of pre-endoscopy anxiety level on tolerance of the procedure and the amount of sedative drug dose. Endosk Gastrointest. 2011;19(2):47-51. http://endoskopi .tgv.org.tr/journal/8/pdf/77.pdf. Accessed on December 9, 2019.

11. Ersöz F, Toros A, Aydoğan G, Bektaş H, Ozcan O, Arikan S. Assessment of anxiety levels in patients during elective upper gastrointestinal endoscopy and colonoscopy. Turk J Gastroenterol. 2010;21(1):29-33. doi:10.4318/tjg.2010.0044

12. Kutlutürkan S, Görgülü U, Fesci $H$, Karavelioglu A. The effects of providing pre-gastrointestinal endoscopy written educational material on patients' anxiety: A randomised controlled trial. Int J Nurs Stud. 2010;47(9):1066-1073. doi:10.1016/j.ijnurstu.2010.01.007

13. Behrouzian F, Sadrizadeh N, Nematpour S, Seyedian SS, Nassiryan M, Zadeh AJF. The effect of psychological preparation on the level of anxiety before upper gastrointestinal endoscopy. J Clin Diagn Res. 2017;11(7):VC01-VC04. doi:10.7860/JCDR/2017/24876.10270

14. El-Hassan H, McKeown K, Muller A. Clinical trial: Music reduces anxiety levels in patients attending for endoscopy. Aliment Pharmacol Ther. 2009;30(7):718-724. doi:10.1111/j.1365-2036.2009.04091.x

15. Pehlıvan S, Ovayolu N, Koruk M, Pehlıvan Y, Ovayolu O, Gülşen MT. Effect of providing information to the patient about upper gastrointestinal endoscopy on the patient's perception, compliance and anxiety level associated with the procedure. Turk J Gastroenterol. 2011;22(1):10-17. doi:10.4318/tjg.2011.0150

16. Walmsley R, Montgomery S. Factors affecting patient tolerance of upper gastrointestinal endoscopy. J Clin Gastroenterol. 1998;26(4):253-255. doi:10.1097/00004836-199806000-00006 
17. Seip B, Huppertz-Hauss G, Sauar J, Bretthauer M, Hoff G. Patients' satisfaction: An important factor in quality control of gastroscopies. Scand J Gastroenterol. 2008;43(8):1004-1011. doi:10.1080/00365520801958592

18. Thanvi B, Munshi S, Vijayakumar N, Taub N, Lo T. Acceptability of oesophagogastroduodenoscopy without intravenous sedation: Patients' versus endoscopist's perception with special reference to older patients. Postgrad Med J. 2003;79(937):650-651. doi:10.1136/pmj.79.937.650

19. Liu YY, Liu YQ, Petrini MA. Effect of information of patients' coping style on pregastroscopy anxiety. Gastroenterol Nurs. 2018;41(1): 47-58. doi:10.1097/SGA.0000000000000302

20. van Vliet MJ, Grypdonck M, van Zuuren FJ, Winnubst J, Kruitwagen C. Preparing patients for gastrointestinal endoscopy: The influence of information in medical situations. Patient Educ Couns. 2004;52(1):23-30. doi:10.1016/s0738-3991(02)00245-8

21. Toomey D, Hackett-Brennan M, Corrigan G, Singh C, Nessim G, Balfe P. Effective communication enhances the patients' endoscopy experience. Ir J Med Sci. 2016;185(1):203-214. doi:10.1007/s11845015-1270-0

22. Nasiri J, Khatib N, Kheiri S, Najafi M. The influence of escort during upper endoscopy and colonoscopy on patient satisfaction and anxiety. J Family Med Prim Care. 2016;5(1):134-138. doi:10.4103/22494863.184638

23. Shapira M, Tamir A. Presence of family member during upper endoscopy: What do patients and escorts think? J Clin Gastroenterol. 1996;22(4):272-274. doi:10.1097/00004836-199606000-00006

24. Ladas S, Aabakken L, Rey J, et al. Use of sedation for routine diagnostic upper gastrointestinal endoscopy: A European Society of Gastrointestinal Endoscopy Survey of National Endoscopy Society Members. Digestion. 2006;74(2):69-77. doi:10.1159/000097466

25. Riphaus A, Geist F, Wehrmann T. Endoscopic sedation and monitoring practice in Germany: Re-evaluation from the first nation- wide survey 3 years after the implementation of an evidence and consent based national guideline. Z Gastroenterol. 2013;51(9): 1082-1088. doi:10.4253/wjge.v7.i2.102

26. Ladas S, Satake Y, Mostafa I, Morse J. Sedation practices for gastrointestinal endoscopy in Europe, North America, Asia, Africa and Australia. Digestion. 2010;82(2):74-76. doi:10.1159/000285248

27. Cohen L, Wecsler J, Gaetano J, et al. Endoscopic sedation in the United States: Results from a nationwide survey. Am J Gastroenterol. 2006;101(5):967-974. doi:10.1111/j.1572-0241.2006.00500.x

28. Wang $\mathrm{T}$, Lin J. Worldwide use of sedation and analgesia for upper intestinal endoscopy: Sedation for upper Gl endoscopy in Taiwan. Gastrointest Endosc. 1999;50(6):888-889. doi:10.1016/s00165107(99)70188-4

29. Faulx A, Vela S, Das A, et al. The changing landscape of practice patterns regarding unsedated endoscopy and propofol use: A national Web survey. Gastrointest Endosc. 2005;62(1):9-15. doi:10.1016 /s0016-5107(05)00518-3

30. Bruhn J. The doctor's touch: Tactile communication in the doctor-patient relationship. South Med J. 1978;71(12):1469-1473. doi:10.1097/00007611-197812000-00008

31. Watson J, Goss C, Phelps G. Audit of sedated versus unsedated gastroscopy: Do patients notice a difference? J Qual Clin Pract. 2001;21(1-2):26-29. doi:10.1046/j.1440-1762.2001.00391.x

32. Woloshynowych M, Oakley D, Saunders B, Williams C. Psychological aspects of gastrointestinal endoscopy: A review. Endoscopy. 1996;28(9):763-767. doi:10.1055/s-2007-1005602

33. Comstock L, Hooper E, Goodwin J. Physician behaviours that correlate with patient satisfaction. J Med Educ. 1982;57(2):105-112. doi:10.1097/00001888-198202000-00005

34. Tierney M, Bevan R, Rees C, Trebble T. What do patients want from their endoscopy experience? The importance of measuring and understanding patient attitudes to their care. Frontline Gastroenterol. 2016;7(3):191-198. doi:10.1136/flgastro-2015-100574 